\title{
Abstract not submitted
}

From Epigenetics and Chromatin: Interactions and processes

Boston, MA, USA. 11-13 March 2013

Published: 18 March 2013

doi:10.1186/1756-8935-6-S1-07

Cite this article as: : Abstract not submitted. Epigenetics \& Chromatin

2013 6(Suppl 1):07.

Submit your next manuscript to BioMed Central and take full advantage of:

- Convenient online submission

- Thorough peer review

- No space constraints or color figure charges

- Immediate publication on acceptance

- Inclusion in PubMed, CAS, Scopus and Google Scholar

- Research which is freely available for redistribution 